\section{Anatomia das Moléculas}

\section{Sobre o Livro}

Somos feitos de moléculas e precisamos de moléculas para tudo o que fazemos, até para pensar e dormir - elas estão em nós e em tudo à nossa volta. A linguagem molecular é hoje comum a muitos domínios do conhecimento, e o seu estudo já não é território exclusivo da química. Anatomia das Moléculas introduz-nos aos conceitos necessários para entendermos a relação entre as estruturas, as propriedades e as transformações das moléculas.

Este livro conta uma história que começa com os átomos e a explicação de como estes produzem moléculas com uma grande diversidade de estruturas. Prossegue com o porquê de ser a estrutura molecular de cada substância determinante para as suas propriedades - para ser um líquido, um sólido ou um gás, para ser estável ou instável. Finalmente, aborda a reatividade das moléculas - por que reagem, ou não, umas com as outras e com que velocidade o fazem.

Nesta obra, os conceitos são apresentados e discutidos de forma simples e concisa, acessível ao não-iniciado, mas sem esquecer o rigor e estimulando o leitor a ir mais longe. Um livro essencial que, guiando-nos pela anatomia das moléculas, nos dá um olhar novo sobre o que se passa connosco e à nossa volta, todos os dias.

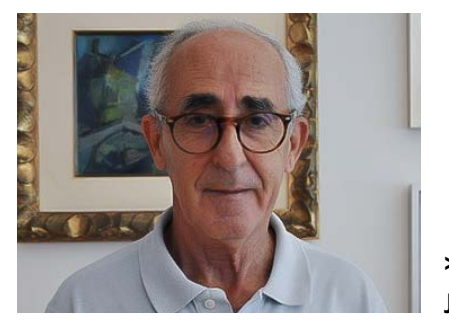

J. A. Martinho Simões

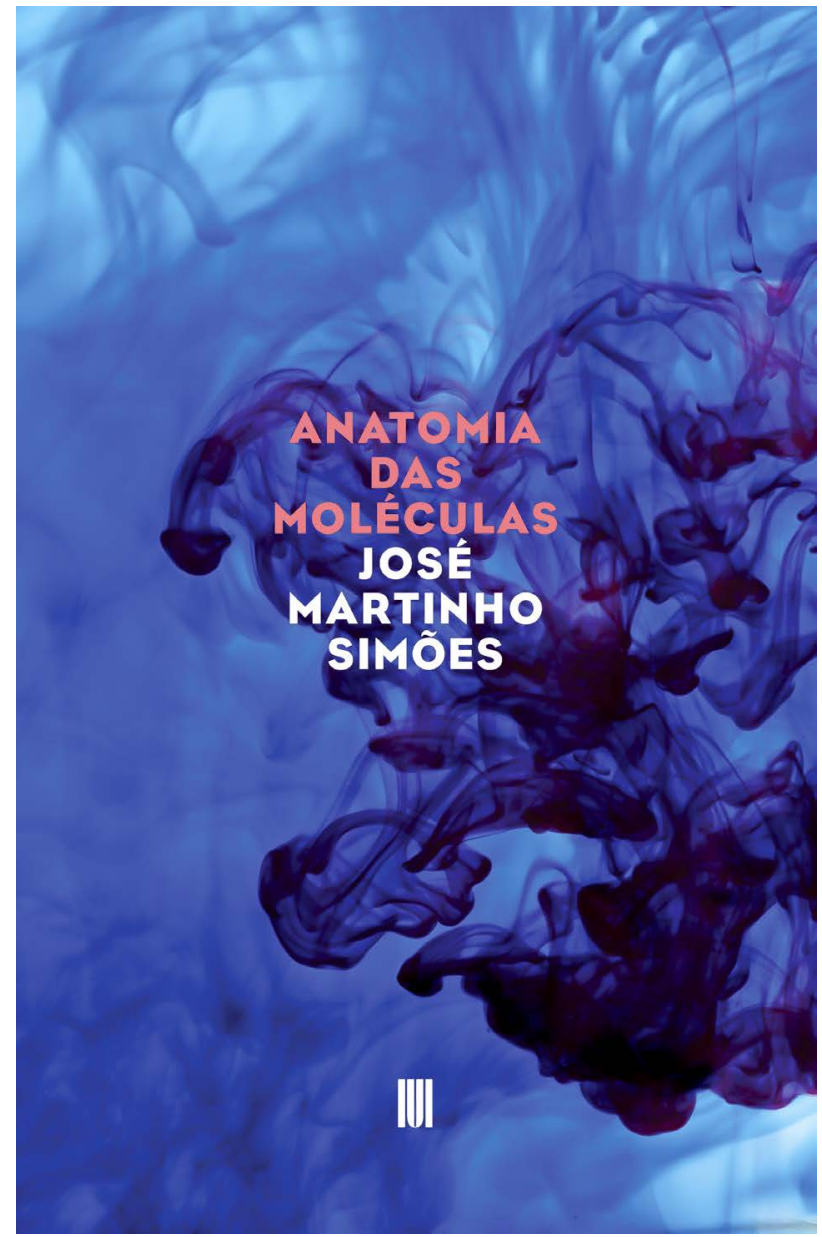

Imprensa da Universidade de Lisboa ISBN: 978-989-8928-27-6

\section{Sobre o Autor}

José Martinho Simões é Professor Catedrático aposentado da Faculdade de Ciências da Universidade de Lisboa. Os seus interesses científicos situam-se na área da energética molecular. Obteve o doutoramento em Engenharia Química no Instituto Superior Técnico, em 1981, e realizou um pós-doutoramento no California Institute of Technology, EUA (1982-83). Em 1988-89, foi visiting research officer no National Research Council of Canada e, em 1996-97, foi guest researcher no National Institute of Standards and Technology, EUA. Foi secretário-geral e presidente da Sociedade Portuguesa de Química. Foi diretor do Instituto de Tecnologia Química e Biológica (ITQB) da Universidade Nova de Lisboa (2008-11) e diretor da Faculdade de Ciências da Universidade de Lisboa (2014-18). Recebeu o Prémio Ferreira da Silva da Sociedade Portuguesa de Química em 2006. 